\title{
Consumer reactions to corporate tax strategies: the role of political ideology
}

Dr. Paolo Antonetti PhD, MSc, BA*

Lecturer (Assistant Professor) in Marketing

Queen Mary University of London

School of Business and Management

p.antonetti@qmul.ac.uk

$+44(0) 2078826478$

\section{Mattia Anesa MSc, BComm}

PhD Candidate

University of Queensland

UQ Business School

m.anesa@business.uq.edu.au

$+61733468100$

The authors would like to thank Gemma Irving for her feedback on an earlier version of the paper. 


\title{
Consumer reactions to corporate tax strategies: the role of political ideology
}

\begin{abstract}
This study contributes to research on how stakeholders react to corporate tax strategies (CTSs). In two experiments we show that consumers are more likely to react negatively to 'aggressive' rather than to reward 'conservative' CTSs. The impact of CTSs on consumer reactions is mediated by the perceived ethicality of the firm and moderated by individuals' political identification. Right-leaning consumers are less likely than left-leaning consumers to punish companies engaging in tax avoidance. This moderation depends on the personal connection customers have with a particular brand: both left-leaning and right-leaning consumers punish firms they feel close to when such firms engage in aggressive CTSs. The study extends our understanding of the benefits and risks associated with different CTSs. It contributes to debates on the morality of CTSs, showing that political ideology shapes individuals' perceived ethicality of corporations engaged in aggressive tax avoidance.
\end{abstract}

Keywords: Corporate tax avoidance; Corporate Social Responsibility; Moral Foundations Theory; Corporate reputation; Corporate Social Irresponsibility; Political Ideology. 


\section{Introduction}

There is increasing attention on the morality of corporate tax strategies (CTSs) that try to minimize as much as possible corporation's tax liabilities (Dowling, 2014; Scheffer, 2013; Sikka, 2010). Global corporations are accused of exploiting national rules in order to pay low taxes on profits made in jurisdictions where they record high sales (Ting, 2014).

Past research has focused mostly on the macro level (e.g., Scheffer, 2013) examining whether aggressive minimization strategies generate negative reactions from stakeholders that affect corporate performance. Some authors find an overall negative impact of aggressive CTSs on firm value (e.g., Hanlon and Slemrod, 2009) while others find no significant overall impact (e.g., Gallemore et al., 2014). Few studies, however, examine how CTSs can affect psychologically organizational stakeholders (Huang and Watson, 2015). Hardeck and Hertl (2014) provide a first examination of how CTSs impact consumer behavior, showing that individuals are willing to punish companies adopting aggressive CTSs and likely to reward companies that do not plan proactively to minimize their tax burden.

Some scholars argue that tax planning decisions should be considered as part of an organization's Corporate Social Responsibility (CSR) profile (Dowling, 2014; Sikka, 2010; Scheffer, 2013). Companies with a poor CSR record are in fact more likely to employ aggressive CTSs (Hoi et al., 2013; Lanis and Richardson, 2015). To the best of our knowledge, however, no study has examined to what extent stakeholders' reactions to CTSs are motivated by their inferences of corporate ethicality. Although scholars assume that tax planning leads to ethical judgments (Hardeck and Hertl, 2014), we test this assumption explicitly. Since organizations are increasingly keen to present their CTSs as responsible in the hope that it might engender positive effects (Bhattacharya et al., 2009; Hardeck and Hertl, 2014) it is important to probe that such expectation holds empirically. 
Tax research has shown that political beliefs do not influence individual tax compliance (Bobek et al., 2013; Li et al., 2011). Consequently, both right-leaning and left-leaning individuals condemn tax evasion. On the other hand, while many on the left condemn tax avoidance, it is common for right-wing politicians and commentators to justify the use of avoidance schemes (e.g., Scheiber and Cohen, 2015). This evidence is consistent with Moral Foundations Theory (MFT) (Graham et al., 2009) that suggests the existence of systematic differences in the moral concerns of people with different political beliefs. On the basis of this theory we hypothesize that left-leaning consumers, more than right-leaning consumers, perceive aggressive CTSs as unethical. We also hypothesize that such moderation disappears when consumers evaluate companies they feel connected to (Escalas, 2004). In these circumstances, aggressive CTSs attract the condemnation of both right-leaning and leftleaning consumers.

We propose a model of moderated-mediation that explains how individuals' political ideology moderates the influence of different CTSs on consumers' reactions. A deeper analysis of the psychology of stakeholders' reactions to CTSs is necessary to enhance our understanding of under what circumstances reports of corporate tax avoidance can generate negative reactions from observers. Evidence that consumers make ethical inferences on the basis of tax information offers a further argument in support of the inclusion of tax planning within a company's CSR profile (Dowling, 2014). Tax avoidance poses a serious threat to brand relationships. Even though consumers who share right-leaning beliefs in general have less negative reactions to tax avoidance, both right-leaning and left-leaning consumers are critical of aggressive strategies carried out by companies they feel close to. On the other hand, conservative CTSs have only a small beneficial effect for the adopter. From the perspective of aligning strategic decision-making and decisions about taxation (Glaister and 
Hughes, 2008) the study offers a realistic assessment of the potential benefits and risks associated with different CTSs.

Furthermore, we contribute to the literature on CSR that studies cases of unethical corporate behavior (e.g., Grappi et al., 2013; Huber et al., 2010). Firstly, while past research focuses on clear cases of irresponsibility (e.g., Grappi et al., 2013), examining a practice which is not universally condemned, we highlight how judgments of ethicality are informed by: 1) the information presented, 2) the values of the observer, and 3) the relationship between the observer and the brand. Secondly, past studies analyzed how an observers' relationships with the brand influences reactions to potentially questionable behavior (e.g., Trump, 2014). Our findings complement this approach by studying the interplay between (political) beliefs of the observer and his/her relationship with the company. Thus, the findings extend our analysis of how consumers make complex ethicality judgments.

\section{Research background}

\subsection{Aggressive and Conservative CTSs}

We conceptualize CTSs as corporate 'efforts to minimize tax liabilities' (Hardeck and Hertl, 2014: 310). CTSs range from illegal tax evasion to legal tax minimization (Culiberg and Bajde, 2014). Our focus rests on legal CTSs with a debatable ethical content. The adjective aggressive is commonly attributed to CTSs that are perceived as leaning towards a literal interpretation of regulation and consider acceptable the exploitation of legal loopholes Hoi et al., 2013). Conversely, conservative CTSs are perceived as in line with the intention of the legislator regardless of whether a literal interpretation would allow for a more effective (lower) tax liability (Dowling, 2014). We study how stakeholders perceive aggressive/conservative CTSs that are reported by the media (Hardeck and Hertl, 2014). 


\subsection{CTSs and stakeholders' responses}

Scholars suggest that stakeholders react negatively to aggressive CTSs. Social movements promote a fairer approach to business taxation (see Tax Justice Network, 2014) and critics point to the inconsistency between a 'corporate citizenship' discourse and the use of aggressive CTSs (Sikka, 2010).

Investors can also react negatively to aggressive CTSs (Hanlon and Slemrod, 2009). This effect appears dependent on external circumstances; especially the damaging effect that being branded as a tax shirker could have on consumer behavior (Cloyd et al., 2003). Contrasting evidence shows that aggressive CTSs do not have any adverse effect on organizational performance (Gallemore et al., 2014).

The conceptual argument that underpins much of existing normative research is that consumers will punish aggressive CTSs because they perceive them as unjust (Dowling, 2014; Sikka and Willmot, 2013). Similarly, with conservative CTSs, individuals should reward companies who are perceived as acting fairly (Scheffer, 2013). In other words, CTSs influence consumers' perception of the morality of an organization. To the best of our knowledge, however, there is no existing evidence that tests explicitly this assumption (Huang and Watson, 2015).

Brunk $(2010 ; 2012)$ proposes a construct called Consumer Perceived Ethicality (CPE) as an overall assessment of an organization's ethical conduct. She argues that consumers use a mixture of consequentialist and deontological arguments to assess the morality of a corporation. We hypothesize that aggressive CTSs are likely to skew such judgments in a negative direction, leading to lower perceptions of ethicality. Conservative CTSs should instead lead to a perception of increased ethicality. 
H1a: Aggressive CTSs (when compared to a control) have a negative influence on the perceived ethicality of a target organization.

H1b: Conservative CTSs (when compared to a control) have a positive influence on the perceived ethicality of a target organization.

\subsection{Consumers' responses to aggressive versus conservative CTSS}

Since tax rules represent codified legal obligations, the extent to which CTSs can represent examples of positive or negative CSR is debated (Hasseldine and Morris, 2013). Customers are less likely to reward companies' CSR activities that they consider are caused by strategic or selfish motives (Skarmeas and Leonidou, 2013). Reports about conservative CTSs could be easily discounted by consumers. Taxation is a legal requirement which is enforced through, among others, administrative penalties for irregularities and cost/timeconsuming audits. Consequently, companies adopting conservative CTSs might be perceived as merely trying to minimize risks and costs rather than behaving ethically (Hasseldine and Morris, 2013).

Furthermore, because most consumers have a limited ability to understand the legal and moral intricacies of tax decisions, positive outcomes are more likely to be attributed to contextual circumstances, while negative outcomes to the character of the actor (Ybarra, 2002). When motivations about the adoption of conservative CTSs are not provided, individuals might attribute these practices to external circumstances (e.g., legal risks) and therefore discount them as a sign of ethicality (Vonk, 1999).

Evidence provided by Hardeck and Hertl (2014), however, contradicts this argument. The authors document a positive, albeit small, effect of conservative CTSs on consumer reactions. Research on CSR supports this argument, showing that organizations can be punished as well 
as rewarded for their ethical conduct (e.g., Bhattacharya et al., 2009; Trudel \& Cotte, 2009). Consequently, we hypothesize a positive (negative) effect of conservative (aggressive) CTSs, although we expect to observe differences on the relative impact of the two strategies (Hardeck and Hertl, 2014)

H2a: Aggressive CTSs (when compared to a control) have a negative influence on attitudes towards the company and purchase intentions (PI), and a positive influence on negative word of mouth (NWOM).

H2b: Conservative CTSs (when compared to a control) have a positive influence on attitudes towards the company and purchase intentions (PI), and a negative influence on negative word of mouth (NWOM).

H3: Perceived ethicality mediates the influence of CTS condition on attitudes towards the company, purchase intentions (PI) and negative word of mouth (NWOM).

\subsection{Responses to CTSs: insights from MFT}

Despite taxes being a common topic in political debates, there is limited evidence on how political views shape reactions to taxation. Empirical studies have demonstrated the positive attitudes toward tax compliance of individuals with a pro-democracy inclination (Torgler and Schneider, 2007) as well as its correlation with political factors like satisfaction for the democratic system and their politicians (Lago-Peñas and Lago-Peñas, 2010), trust in governmental institutions (Cummings et al., 2009) and perceived effectiveness of public service delivery (Molero and Pujol, 2012).

Political ideology refers to the analysis of individual differences in values, attitudes and beliefs about society and politics (Jost et al., 2008). Individual political ideology is evaluated through political identification with a certain party that represents specific values and 
political ideas (Mehrabian, 1996). In the Western tradition, political beliefs are organized around the left-right dimension (Bobbio, 1996). Li and colleagues (2011) examine whether political inclination has an effect on the likelihood of voluntary donations to private charities (i.e., philanthropy) versus donations to governmental authorities (i.e., taxes). The authors find no difference in attitudes between the two groups and argue that both right-leaning and leftleaning individuals prefer voluntary giving to taxation because of a limited trust on the efficiency of the state. Another recent study finds no correlation between the political ideology of the participants and 1) their perception of fairness of taxation, 2) their norms in relation to taxes, and 3) their intentions to comply with tax regulations (Bobek et al., 2013). This evidence would suggest that, despite differing political views between left and right on the optimal size of the state and the role of government, individual attitudes towards tax compliance are not affected by political beliefs (see Everett, 2013).

Research on MFT shows how people on the right and people on the left differ predictably on the dimensions they use to make moral decisions (Graham et al., 2009; Haidt and Joseph, 2004). While right-leaning individuals mostly evaluate morality on foundations of purity, respect for authority and support for the in-group, left-leaning individuals are most concerned with issues of harm and fairness (Graham et al., 2009). Aggressive CTSs are practices that potentially contradict the foundation of fairness.

This moral intuition supports non-kin solidarity (Haidt and Joseph, 2004). Individuals who score high on fairness consider equal treatment and the respect of general rules as particularly important (Jost et al., 2008). Aggressive CTSs are a direct challenge to the principle of mutual cooperation because they allow some companies to pay less tax than others and less than what was intended by the legislator (Dowling, 2014). Aggressive CTSs contradict a 
moral narrative important to the political left that focuses on the reduction of inequality through institutions that eliminate or reduce exploitation in society (Smith, 2003).

Right-leaning individuals, on the other hand, have a higher acceptance of inequality (Jost et al., 2003) and show a tendency to justify the status quo (Jost et al., 2003; Jost et al., 2008). This does not mean that those on the right will not react negatively to aggressive CTSs. Fairness of treatment, although less important than other dimensions, still plays a role in right-wing morality (Graham et al., 2009). Furthermore, under certain circumstances, aggressive CTSs could also be construed as an issue of disloyalty to the in-group. When multinational companies shift some of their profits to jurisdictions with lower tax rates, they might be perceived as betraying the community that hosts their operations (see Johnson and Holub, 2003).

To the extent that conservative CTSs are perceived as a sign of CSR, it is also expected that those on the left would reward the adoption of such strategies more strongly. MFT suggests that any positive impact should be stronger for left-leaning consumers because the dimension of fairness is more important for them (Smith, 2003).

H4: Left-leaning (right-leaning) consumers perceive CTSs as a strong (weak) sign of corporate ethicality and therefore have strong (weak) reactions to reports about CTSs.

\subsection{CTSs and brand relationships}

Although left-leaning consumers are more likely to consider CTSs as a sign of unethical behavior, this pattern of evaluations might change when reports of CTSs affect a company that is strongly connected with the self (Escalas, 2004). In this case consumers are more likely to rely on their own personal interests and consider to what extent the newly acquired information affects them directly (Hunt et al., 2010). On the contrary, when tax policies are 
attributed to a company that one is not connected to, it is likely that the evaluation will focus more on the underlying moral principles (Hunt et al., 2010).

Research shows that consumers are often willing to overlook the negative information about companies they feel close to (Cheng et al., 2012). This buffering effect is a self-defense mechanism: criticism of a loved company is perceived as a threat to the self (Cheng et al., 2012). Researchers have shown however that such a defensive reaction depends on the nature of the information provided. While product or service failures (e.g., product recalls, product defects) tend to be discounted, this is not the case for negative reports that have a moral content (e.g., racial discrimination, labor exploitation) (Folkes and Kamins, 1999; Trump, 2014). Information about moral failings is able to deteriorate the quality of the relationship with a brand because it is considered more diagnostic of the character of the brand (Huber et al., 2010; Trump, 2014).

H5: Consumers closely connected to a brand will react negatively to reports of aggressive CTSs and positively to reports of conservative CTSs regardless of their political identification.

Figure 1 summarizes our model of moderated mediation models in relation to both aggressive and conservative tax strategies. In Study 1 we test both models examining consumers' reactions to a fictitious brand and manipulating information about CTSs. Study 2 tests the same models in relation to real brands and varying the level of personal connection between consumers and the target company. In both studies we focus on three potential outcomes of exposure to reports about CTSs: attitude towards the brand, intentions to spread negative word of mouth (NWOM) and purchase intentions (PI). 


\section{Study 1}

\subsection{Method}

We conducted a between-subjects experiment. Participants were presented with one of three versions of a company profile. The first two profiles manipulated the relevant CTS (aggressive or conservative) while the control condition contained no information about the tax practices of the firm. 439 participants were recruited online through Amazon Mechanical Turk (AMT) in exchange for \$.75 (Paolacci and Chandler, 2014). The survey lasted six minutes on average. We retained for analysis 402 complete surveys. The survey software randomly allocated participants to one of three conditions where they read a (fictitious) company profile. After this stage, participants answered a number of scales. To encourage participants' attention, at the beginning of the survey we used an instructional manipulation check (Oppenheimer et al., 2009). All participants were US residents. 54\% of our participants were male. $38 \%$ less than college educated, $48 \%$ held a college degree and $14 \%$ a graduate degree. $31 \%$ of the participants were aged between 18 and 29 years old, $50 \%$ between 30 and 49 years old and $19 \%$ above 50 .

Following Hardeck and Hertl (2014) we employed three profiles: an aggressive CTS, a conservative CTS and a control condition where no information about CTS was provided. We used a fictitious company and manipulated the relevant information about CTS on the basis of previous research (Hardeck and Hertl, 2014). Participants in the aggressive CTSs condition read of a company that "[...] has recently been the target of criticism [...]" because it "implements complex tax planning strategies that allow paying very little tax to the IRS [Internal Revenue Service] compared to its revenues. The company's tax strategies exploit loopholes in international regulations aggressively and allow $F N^{1}$ to minimize its tax burden

\footnotetext{
${ }^{1}$ Acronym of a fictitious company.
} 
towards the IRS. Many of FN's tax policies do not have real economic substance. In other words, they are simply accounting practices that allow the company to shift funds internally in order to minimize its tax liabilities towards the US authorities." In the conservative CTSs condition participants read of a firm that "[..] has recently been praised [...]" because of " $a$ fair approach to taxation" that translates into paying "to the IRS an amount of taxes that is proportionate to its revenues. The company's tax strategies do not exploit loopholes in international regulations and FN's tax burden towards the IRS is in line with its overall revenues. All of FN's tax strategies are based on transactions with real economic substance. In other words, the company does not employ accounting practices that manipulate its accounts artificially in order to minimize its tax liabilities towards the US authorities." Participants considered the claims made in the scenario as clear $\left(M_{\text {aggressive }}=5.79, M_{\text {conservative }}\right.$ $=5.73, M_{\text {control }}=5.83,1=$ unclear, $7=$ clear; $\left.F(2,400)=.19, p=.827\right)$.

Scales from previous research were employed to measure the main constructs in our model. Perceived ethicality $(\alpha=.95 ; \mathrm{CR}=.96 ; \mathrm{AVE}=.83)$ was measured through the items developed by Brunk (2012). We adopted the measure of political ideology $(\alpha=.92$; CR $=$ .94 ; AVE $=.71)$ developed by Mehrabian (1996). The scale was coded so that lower scores indicate left-leaning political beliefs. Attitudes towards the corporation $(\alpha=.95 ; \mathrm{CR}=.96$; $\mathrm{AVE}=.87)$ were measured on a 7-point scale and using the four items adopted by Hardeck and Hertl (2014). Negative word-of-mouth $(\alpha=.95 ; \mathrm{CR}=.97$; AVE $=.90)$ was also borrowed from previous research (Grégoire and Fisher, 2006). The purchase intentions measure $(\alpha=.95 ; \mathrm{CR}=.97 ; \mathrm{AVE}=.91)$ was also consistent with previous research (e.g., Grappi et al., 2013). The reliability indicators were all above recommended thresholds (Fornell and Larcker, 1981). All factor loadings were above .70 (Bagozzi and Yi, 1988) and good discriminant validity was demonstrated by the Maximum Shared Variance and Average 
Shared Variance being lower than the AVE for all constructs (Hair et al., 2010). The FornellLarcker criterion was also supported for all constructs.

\subsection{Results}

We used the average of two items to check the effectiveness of the manipulations (e.g., "The company described engages in tax avoidance activities"; $1=$ strongly disagree, $7=$ strongly agree). We found that the different CTSs were correctly identified across the three experimental groups $\left(M_{\text {aggressive }}=5.82 ; M_{\text {conservative }}=2.03 ; M_{\text {control }}=2.80, F(2,399)=238.47\right.$, $p<.001)$ and all paired comparisons yield statistically significant differences.

An ANOVA with planned contrasts assessed the effects of different CTSs (Table 1). Consistent with $\mathrm{H} 1 \mathrm{a}$ and $\mathrm{H} 1 \mathrm{~b}$, aggressive (conservative) CTSs damage (improve) perceptions of company ethicality $(F(2,399)=121.78, p<.001)$. Results also confirm a main effect in terms of attitudes $(F(2,399)=78.52, p<.001)$. Consistent with our hypotheses, engaging in aggressive CTSs translates into potential negative word of mouth $(F(2,399)=58.23, p<$ $.001)$. Results for our purchase intentions measure show that aggressive strategies can have a clear damaging effect $(F(2,399)=49.09, p<.001)$ although planned contrasts show that conservative CTSs do not have a direct effect on this measure. Comparisons across the three conditions also show that conservative CTSs are evaluated significantly better than aggressive CTSs.

\section{INSERT TABLE 1 HERE}

Using PROCESS (Hayes, 2013, model 7) we estimated two moderated mediation models: one for the aggressive condition and one for the conservative condition. The dichotomous independent variable compares the manipulations (coded as "1") versus the control condition (coded as “-1"). We calculated 95\% confidence intervals using bias-corrected and accelerated bootstrap with 10,000 resamples (Hayes, 2013). In each case we compared the relevant CTS 
condition to the control, the two models were estimated on 272 and 265 cases respectively (Table 2). In order to estimate the impact on our three outcomes we ran three separate models, one for each dependent variable. In both sets of models, political ideology, consistently with H4, moderates the relationship between CTS and CPE. All our research hypotheses are supported by the data. In general, the adoption of aggressive (conservative) CTSs produces negative (positive) consequences in terms of 1) attitudes towards the company, 2) word of mouth, and 3) purchase intentions. Across all three models, this effect appears to be mediated by CPE, consistently with $\mathrm{H} 2 \mathrm{a}, \mathrm{H} 2 \mathrm{~b}$ and $\mathrm{H} 3$.

Conditional indirect effects (Table 3) show that, while both left-leaning and right-leaning consumers have a negative reaction towards aggressive CTSs and a positive view of companies adopting conservative CTSs; the former are much more sensitive to this issue. ${ }^{2}$

\section{INSERT TABLE 2 HERE}

\section{INSERT TABLE 3 HERE}

\subsection{Discussion}

The findings support our conceptual model. Consumers draw moral judgments about the ethicality of the firm from information about CTS. In turn, CPE mediates consumers' reactions (H3). While reports of aggressive CTSs have a strong negative influence on consumer reactions $(\mathrm{H} 2 \mathrm{a})$, the evidence of a positive effect of conservative CTSs in line with $\mathrm{H} 2 \mathrm{~b}$ is much weaker. Evidence of a positive indirect effect of conservative CTSs on our dependent variables, supports our conceptual model (Zhao et al., 2010). However, conservative CTSs appear to have only an indirect effect on purchase intentions through the mediation of perceived ethicality. This finding is consistent with past research on CSR

\footnotetext{
${ }^{2}$ We estimated the models introducing age, gender and level of education as covariates. Findings are robust to the introduction of these controls.
} 
(Trudel and Cotte, 2009) as well as Hardeck and Hertl's (2014) analysis of how German consumers react to information about CTSs.

Despite past research findings, that political views do not influence attitudes towards individual tax compliance (Bobek et al., 2013), our study shows that political ideology moderates how individuals react to media reports about CTSs (H4). Although both rightleaning and left-leaning consumers are critical, the effect is much stronger for the latter group. Also, those with left-wing views are more likely to reward companies who implement conservative CTSs. The study presented, however, examined participants' reactions towards a fictitious organization. To improve the external validity of our research we extended our analysis to reports that involve real brands.

\section{Study 2}

\subsection{Method}

We conducted a 3 (CTSs: aggressive, conservative, control) X 2 (self-brand connection: favorite, least favorite) between-subjects experiment. The experiment focused on sportswear brands. Participants were presented with a list of the twenty most popular sportswear brands (retrieved from www.statista.com). Out of these brands participants indicated those they are aware of and their favorite and least favorite option. To manipulate the second factor in our design, half of the participants evaluated CTSs' information in relation to their favorite brand and the other half in relation to their least favorite brand. In the control condition, where no information about tax was provided, participants were simply asked to think about their perception of the brand for a few moments before proceeding with the survey. 328 participants were recruited on AMT but we obtained 306 complete surveys used for analysis. The survey lasted on average nine minutes and participants were awarded $1 \$$ for participation. All other procedures and sample requirements were consistent with Study 1. 
$51 \%$ of participants were male. In terms of education, $36 \%$ were less than college educated, $52 \%$ held an undergraduate degree and $12 \%$ a graduate degree. Participants varied significantly also in terms of age. $29 \%$ between 18 and 29 years old, $50 \%$ between 30 to 49 years old and $21 \%$ above 50 .

With the exception of the name of the company, the information provided on CTSs was the same as that used in Study 1. Participants were asked to imagine that they had read the news about the company's CTSs from "their favorite newspaper or other trusted source". Participants rated the scenarios as clear $\left(1=\right.$ unclear, $7=$ clear; $M_{\text {aggressive }}=5.48, M_{\text {conservative }}=$ $5.88, F(2,200)=2.06, p=.106)$.

We adopted the same measures already used in Study 1. Reliability indicators were satisfactory for all constructs: $\mathrm{CPE}(\alpha=.95 ; \mathrm{CR}=.96 ; \mathrm{AVE}=.84)$, political ideology $(\alpha=$ $.93 ; \mathrm{CR}=.94 ; \mathrm{AVE}=.73)$, attitudes towards the corporation $(\alpha=.96 ; \mathrm{CR}=.97 ; \mathrm{AVE}=.89)$, negative word of mouth $(\alpha=.94 ; \mathrm{CR}=.96 ; \mathrm{AVE}=.89)$ and purchase intentions $(\alpha=.97$; CR $=.98 ; \mathrm{AVE}=.95)$. All factor loadings for all scales were above .70 (Bagozzi and Yi, 1988) and we found evidence of good discriminant validity since the Maximum Shared Variance and Average Shared Variance were lower than the AVE for all measures (Hair et al., 2010) and the Fornell-Larcker criterion was supported for all constructs.

\subsection{Results}

As in Study 1 the relevant CTSs are correctly decoded across the two experimental groups $\left(M_{\text {aggressive }}=6.01 ; M_{\text {conservative }}=2.09, t(202)=18.7, p<.001\right)$. We also measured participants' self-brand connection (Escalas, 2004) with the company evaluated in the experiment. As expected, participants have a stronger connection with their favored brands than with the least favorite alternatives $\left(M_{\text {favorite }}=5.01 ; M_{\text {least favorite }}=1.89, t(304)=21.5, p<.001\right)$. 
To test our hypotheses, we ran a series of 2 X 3 ANOVAs using planned contrasts to compare the effect of the tax conditions compared with the control on the outcome variables. All descriptive statistics across conditions are presented in Table 4. As expected we found a main effect of CTSs on CPE $(F(2,300)=97.04, p<.001)$. Planned contrasts indicate that companies engaging in conservative (aggressive) CTSs are perceived as relatively more (less) ethical than the control, while companies practicing aggressive CTSs are considered less ethical than the control. Consistently with Study 1, we also find that conservative CTSs are evaluated better than aggressive CTSs and all differences between these two groups are statistically significant. Unsurprisingly there is also a main effect of company condition $(F(1$, $300)=48.91, p<.001)$. Finally, there is a significant interaction between the two conditions $(F(2,300)=4.47, p<.05)$. Similar results are obtained in relation to the measure of attitudes towards the company. Both the tax strategy condition $(F(2,300)=28.43, p<.001)$ and the company condition $(F(1,300)=28.42, p<.001)$ yield main effects and we find evidence again of a significant interaction $(F(2,300)=3.72, p<.05)$. Consumers have a better evaluation of the company in the control condition when compared to the aggressive CTS and more positive attitudes towards the company in the conservative CTS than towards companies in the control condition. Results in terms of negative word of mouth also show a main effect of CTS $(F(2,300)=27.11, p<.001)$, company condition $(F(1,300)=20.64, p$ $<.001)$ and a significant interaction $(F(2,300)=4.32, p<.05)$. Consistent with our hypotheses, the use of aggressive CTSs increases the likelihood of negative word of mouth. Finally, purchase intentions are also influenced by CTSs $(F(2,300)=7.57, p<.001)$ and company condition $(F(1,300)=538.32, p<.001)$. The interaction term is not statistically significant $(F(2,300)=2.39, p=.09)$. Planned contrasts show that while there is a negative effect of aggressive CTS, the adoption of conservative CTSs does not generate a direct positive effect. 
Taken together these results provide support for H1a, H1b and H2a. Although the absence of a direct effect of conservative CTSs on consumer reactions potentially challenges $\mathrm{H} 2 \mathrm{~b}$, it is possible that consumer reactions are affected indirectly through the paths suggested by our model.

\section{INSERT TABLE 4 HERE}

To estimate our conceptual model, we ran the same analysis conducted in Study 1. We used PROCESS, Model 7 (Hayes, 2013) with the same procedures discussed above. Table 5 shows results of a series of regression models estimated comparing the CTSs conditions to the control for the three dependent variables (attitudes, negative word of mouth and purchase intentions). These analyses were conducted on a sample of 204 participants. CPE mediates consumer reactions, in line with $\mathrm{H} 3$. H4 is also supported because we find an interaction between political identification and the aggressive CTS condition. There is no evidence of moderation, however, in relation to conservative CTSs, a result that is not in line with Study 1. Table 6 shows the indirect effects for the moderated mediation model of aggressive CTSs. Consistent with $\mathrm{H} 4$ we find stronger negative effects for left-leaning individuals. Even though there is no evidence that political ideology moderates the influence of conservative CTSs on ethicality, the indirect effect is statistically significant for attitude (effect: .42, CI from .26 to .60), negative word of mouth (effect: -.21 , CI from -.35 to -.12) and purchase intentions (effect: .43 , CI from .26 to .63). This evidence suggests a positive influence of conservative CTSs on consumer reactions consistent with our theorizing (Zhao et al., 2010).

\section{INSERT TABLE 5 HERE}

\section{INSERT TABLE 6 HERE}

The same analysis was also conducted for both favorite and least favorite brands in order to test H5. We estimated our conceptual model on the sample of participants who evaluated 
their favorite brands $(\mathrm{N}=101$ for aggressive CTSs and $\mathrm{N}=103$ for conservative CTSs) and participants who evaluated their least favorite brands $(\mathrm{N}=103$ for aggressive CTSs and $\mathrm{N}=101$ for conservative CTSs). Consistent with our expectations, political identification does not moderate reactions to aggressive CTSs when a favorite brand is evaluated (interaction effect: .05 , CI from -.06 to .17). However, the moderation is present when the model is estimated for least favorite brands (interaction effect: .12, CI from .04 to .20). The conditional indirect effects are presented in Table 7 and they are in line with H4. Figure 2 and Figure 3 present spotlight analyses that clearly show how 1) right-leaning participants' leniency when evaluating the ethicality of a brand that engages in aggressive CTSs is absent when the consumers have a strong connection to the brand, 2) political identification does not affect judgments of ethicality in relation to conservative CTSs.

INSERT TABLE 7 HERE

INSERT FIGURE 2 HERE

INSERT FIGURE 3 HERE

\subsection{Discussion}

Results obtained from Study 2 examining real companies reflect the findings of Study 1 for fictitious ones. We found support for H1a, H1b, H2a, H3 and partially H4. These results suggest that the reactions of consumers are mediated by CPE and moderated by political ideology.

$\mathrm{H} 2 \mathrm{~b}$ is also formally supported because there is evidence of a positive indirect effect of reports about conservative CTSs on consumer reactions (Zhao et al., 2010). However, 
consistent with Study 1, the effect is small and therefore unlikely to generate significant positive returns.

Interestingly, the moderation of political ideology is not supported for conservative CTSs. This result is likely due to the fact that, when consumers evaluate fictitious brands as in Study 1, the adoption of CSR practices is more indicative of ethicality than in circumstances when consumers have pre-existing beliefs about the brand (Jones et al., 2014: 399). Negative signals are more powerful than positive ones in a moral context (Baumeister et al., 2001). Skowronski and Carlston (1992) suggest that negative behaviors are always more diagnostic than positive moral actions. Hence, political ideology differentiates reactions to aggressive CTSs more reliably than reactions to conservative CTSs.

Finally, H5 is supported. Self-brand closeness eliminates the relative acceptance of rightleaning observers for aggressive CTSs. This finding is in line with work by Trump (2014) showing that consumers close to a brand are willing to justify product-related failures but react negatively to moral-related failures. While the moderation of political ideology is present when assessing the CTSs of distal companies, both left-leaning and right-leaning individuals react negatively to aggressive CTSs by a close brand. Tax policies have a moral relevance for all consumers, irrespective of their political views.

\section{General discussion}

\subsection{Implications for research}

This study advances the tax literature in relation to stakeholders' reactions to tax avoidance (Hardeck and Hertl, 2014). Despite inconsistent findings at the organizational level on how CTSs influence performance (Cloyd et al., 2003; Gallemore et al., 2014), we show that consumers have negative reactions to aggressive practices. Our evidence is in line with 
work by Hardeck and Hertl (2014) and supports the view that engaging in aggressive CTSs poses serious risks (PwC, 2013). We extend previous tax research by clarifying the process underpinning this negative effect. CTSs affect judgments of ethicality and this assessment is moderated by the political ideology of the observer. Nonetheless even consumers with rightleaning political views criticize companies close to the self when these engage in aggressive CTSs. This stresses the fact that tax avoidance presents significant risks for brand relationships.

Previous taxation research has shown that political views do not affect individuals' attitudes towards personal compliance (Bobek et al., 2013; Li et al., 2011). We show that reactions to aggressive CTSs are based on different psychological processes from those that explain personal compliance. Political identification regulates reactions to CTSs (at least in the case of companies not connected to the self). Tax research needs to examine stakeholders' reactions to CTSs as a separate field of study with implications for the psychology of CSR.

Our findings also contribute to the CSR literature by reinforcing an emerging trend highlighted in previous research: retaliations against irresponsible behavior are stronger than rewards for responsible conduct (Trudel and Cotte, 2009). Conservative CTSs, in fact, offer only a small and indirect benefit in terms of consumer reactions. Interestingly Hardeck and Hertl (2014) found, in a sample of German consumers, a stronger positive effect of conservative CTSs than the one we identify in this research. This is likely due to the fact that different countries have different attitudes towards taxation (Alm and Torgler, 2006) and consequently individuals might have different views on the responsibility of corporations as taxpayers. Future research should investigate cross-cultural reactions to CTSs, since tax regulation is increasingly shaped in multi-state arenas (e.g., OECD) and CTSs are often implemented in a plurality of national settings (Lipatov, 2012). 
A further contribution to the CSR literature rests in the analysis of how characteristics of the observers (i.e. political beliefs), information about unethical behavior (i.e., aggressive CTSs) and pre-existing relationships with the brand interact to shape judgments of ethicality. Past research tends to focus on clear cases of irresponsible corporate behavior (e.g., Grappi et al., 2013). Some areas of corporate practice however lead to more complex moral judgments and consumers' interpretation of these practices might involve, as in the case of CTSs, a mix of personal and contextual variables. We contend that further research examining directly what shapes perceptions of ethicality will contribute to both theory and practice by identifying areas that risk generating negative stakeholder reactions.

In this respect, we find that personal beliefs (political ideology) can be less important than brand relationships in defining what is ethically salient. Right-leaning consumers, who usually are less concerned about tax avoidance, react as negatively as left-leaning consumers when companies they feel close to engage in aggressive CTSs. This finding stresses the importance of examining (political) beliefs in context and reflect on the circumstances that shape subtly moral judgments.

\subsection{Implications for practice}

Our results suggest that showcasing a conservative tax conduct might "improve(s) the reputation and perceived trustworthiness of your business" (Fair Tax Mark, 2015). However, companies should expect only minimal returns from the adoption of conservative CTSs. That said, we believe that moral considerations should encourage the adoption of conservative CTSs in all cases; while from a more pragmatic view the adoption of conservative CTSs is an insurance against potential consumer backlash that is likely to be caused by aggressive CTSs (PwC, 2013). 
The findings presented are especially salient for organizations whose target market tends to include consumers with left-leaning political views or whose brand image is associated with liberal beliefs. Although political ideology is not necessarily a variable used commonly in segmentation studies, examinations of consumer values (Kamakura and Novak, 1992) can highlight potential risks for organizations. If potential customers value social justice highly then reports on aggressive CTSs could be very damaging for the organization's ability to expand its customer base.

When considering existing customers, the results indicate that companies should pay particular attention to how CTSs are reported in the media because aggressive CTSs appear to be perceived very negatively by all consumers who feel closely connected to the brand, irrespective of their political views.

\subsection{Limitations and areas for further research}

We present cross-sectional data. Longitudinal studies could explore the duration of negative or positive effects generated by information about CTSs. Furthermore, consumers were informed about CTSs by the report they read. It is possible that the pre-existing level of knowledge of tax regulations might also affect consumers' reactions (Sen et al., 2006).

In this study we focused on one type of CTS (i.e., profit shifting). This practice is arguably the easiest to grasp and has been the focus of recent media coverage. Future research could explore consumers' reactions to less stigmatized types of CTSs.

Future research could also examine whether and how the differing views of right-leaning and left-leaning consumers on the issue of tax avoidance could be reconciled (see Kidwell et al., 2013). Future work could explore ways to reduce the political segmentation currently identified in reactions to media reports about CTSs. It is interesting to notice however that the 
different evaluations between right-leaning and left-leaning consumers disappear when individuals consider brands close to the self. This insight is worthy of further investigation in CSR research. It would be interesting to examine in more depth how and to what extent building a relationship with a brand leads to an expansion of the moral expectations consumers have towards the company (Trump, 2014). This is a research domain that promises to generate important implications for scholars and practitioners. 


\section{References}

Aguinis, H., \& Glavas, A. (2012). What we know and don't know about corporate social responsibility a review and research agenda. Journal of Management, 38(4), 932-968.

Alm, J., \& Torgler, B. (2006). Culture differences and tax morale in the United States and in Europe. Journal of Economic Psychology, 27(2), 224-246.

Bagozzi, R. P., \& Yi, Y. (1988). On the evaluation of structural equation models. Journal of the Academy of Marketing Science, 16(1), 74-94.

Baumeister, R. F., Bratslavsky, E., Finkenauer, C., \& Vohs, K. D. (2001). Bad is stronger than good. Review of General Psychology, 5(4), 323-370.

Bhattacharya, C. B., Korschun, D., \& Sen, S. (2009). Strengthening stakeholder-company relationships through mutually beneficial corporate social responsibility initiatives. Journal of Business Ethics, 85(2), 257-272.

Bobbio, N. (1996). Left and Right. Cambridge, United Kingdom: Polity Press.

Bobek, D. D., Hageman, A. M., \& Kelliher, C. F. (2013). Analyzing the role of social norms in tax compliance behavior. Journal of Business Ethics, 115(3), 451-468.

Brunk, K. H. (2010). Exploring origins of ethical company/brand perceptions - A consumer perspective of corporate ethics. Journal of Business Research, 63(3), 255-262.

Brunk, K. H. (2012). Un/ethical company and brand perceptions: Conceptualising and operationalising consumer meanings. Journal of Business Ethics, 111(4), 551-565.

Cheng, Y. Y.,White, T. B., \& Chaplin, L. N. (2012). The effects of self-brand connections on responses to brand failure: A newlook at the consumer-brand relationship. Journal of Consumer Psychology, 22(2), 280-288. 
Cloyd, C. B., Mills, L. F., \& Weaver, C. D. (2003). Firm valuation effects of the expatriation of US corporations to tax-haven countries. Journal of the American Taxation Association, 25(1), 87-109.

Culiberg, B., \& Bajde, D. (2014). Do you need a receipt? Exploring consumer participation in consumption tax evasion as an ethical dilemma. Journal of Business Ethics, 124(2), 271282.

Cummings, R. G., Martinez-Vazquez, J., McKee, M., \& Torgler, B. (2009). Tax morale affects tax compliance: Evidence from surveys and an artefactual field experiment. Journal of Economic Behavior \& Organization, 70(3), 447-457.

Dowling, G. R. (2014). The curious case of corporate tax avoidance: Is it socially irresponsible? Journal of Business Ethics, 124(1), 173-184.

Escalas, J. E. (2004). Narrative processing: Building consumer connections to brands. Journal of Consumer Psychology, 14(1\&2), 168-180

Everett, J. A. C. (2013). The 12 Item Social and Economic Conservatism Scale (SECS). PLoS ONE. 8. doi:10.1371/journal.pone.0082131.

Fair Tax Mark (2015). Get the Fair Tax Mark. Available at: http://www.fairtaxmark.net/getthe-mark/.

Folkes, V. S., \& Kamins, M. A. (1999). Effects of information about firms' ethical and unethical actions on consumers' attitudes. Journal of Consumer Psychology, 8(3), 243259. 
Fornell, C., \& Larcker, D. F. (1981). Evaluating structural equation models with unobservable variables and measurement error. Journal of Marketing Research, 18(1), 3950.

Gallemore, J., Maydew, E. L., \& Thornock, J. R. (2014). The reputational costs of tax avoidance. Contemporary Accounting Research, 31(4), 1103-1133.

Glaister, K. W., \& Hughes, J. F. (2008). Corporate strategy formulation and taxation: Evidence from UK Firms. British Journal of Management, 19(1), 33-48.

Graham, J., Haidt, J., \& Nosek, B. A. (2009). Liberals and conservatives rely on different sets of moral foundations. Journal of Personality and Social Psychology, 96(5), 1029-1046.

Grappi, S., Romani, S., \& Bagozzi, R. P. (2013). Consumer response to corporate irresponsible behavior: Moral emotions and virtues. Journal of Business Research, 66(10), 1814-1821.

Grégoire, Y., \& Fisher, R. J. (2006). The effects of relationship quality on customer retaliation. Marketing Letters, 17(1), 31-46.

Haidt, J., \& Joseph, C. (2004). Intuitive ethics: How innately prepared intuitions generate culturally variable virtues. Daedalus, 133(4), 55-66.

Hanlon, M., \& Slemrod, J. (2009). What does tax aggressiveness signal? Evidence from stock price reactions to news about tax shelter involvement. Journal of Public Economics, 93(1), 126-141.

Hardeck, I., \& Hertl, R. (2014). Consumer reactions to corporate tax strategies: Effects on corporate reputation and purchasing behavior. Journal of Business Ethics, 123(2), 309326. 
Hasseldine, J., \& Morris, G. (2013). Corporate social responsibility and tax avoidance: A comment and reflection. Accounting Forum, 37(1), 1-14.

Hayes, A. F. (2013). Introduction to Mediation, Moderation and Conditional Process Analysis. New York: Guilford Press.

Hoi, C. K., Wu, Q., \& Zhang, H. (2013). Is corporate social responsibility (CSR) associated with tax avoidance? Evidence from irresponsible CSR activities. The Accounting Review, $88(6), 2025-2059$.

Huang, X. B., \& Watson, L. (2015). Corporate social responsibility research in accounting. Journal of Accounting Literature, 34, 1-16.

Huber, F., Vollhardt, K., Matthes, I., \& Vogel, J. (2010). Brand misconduct: Consequences on consumer-brand relationships. Journal of Business Research, 63(11), 1113-1120.

Hunt, C. V., Kim, A., Borgida, E., \& Chaiken, S. (2010). Revisiting the self-interest versus values debate: The role of temporal perspective. Journal of Experimental Social Psychology, 46(6), 1155-1158.

Johnson, J., \& Holub, M. (2003). Questioning organizational legitimacy: The case of US expatriates. Journal of Business Ethics, 47(3), 269-293.

Jones, D. A., Willness, C. R., \& Madey, S. (2014). Why are job seekers attracted by corporate social performance? Experimental and field tests of three signal-based mechanisms. Academy of Management Journal, 57(2), 383-404.

Jost, J. T., Glaser, J., Kruglanski, A. W., \& Sulloway, F. J. (2003). Political conservatism as motivated social cognition. Psychological Bulletin, 129(3), 339-375. 
Jost, J. T., Nosek, B. A., \& Gosling, S. D. (2008). Ideology: Its resurgence in social, personality, and political psychology. Perspectives on Psychological Science, 3(2), 126136.

Kamakura, W. A., \& Novak, T. P. (1992). Value-system segmentation: Exploring the meaning of LOV. Journal of Consumer Research, 19(1), 119-132.

Kidwell, B., Farmer, A., \& Hardesty, D. M. (2013). Getting liberals and conservatives to go green: Political ideology and congruent appeals. Journal of Consumer Research, 40(2), 350-367.

Lago-Peñas, I., \& Lago-Peñas, S. (2010). The determinants of tax morale in comparative perspective: Evidence from European countries. European Journal of Political Economy, 26(4), 441-453.

Lanis, R., \& Richardson, G. (2015). Is corporate social responsibility performance associated with tax avoidance?. Journal of Business Ethics, 127(2), 439-457.

Li, S. X., Eckel, C. C., Grossman, P. J., \& Brown, T. L. (2011). Giving to government: Voluntary taxation in the lab. Journal of Public Economics, 95(9), 1190-1201.

Lipatov, V. (2012). Corporate tax evasion: The case for specialists. Journal of Economic Behavior \& Organization, 81(1), 185-206.

Mehrabian, A. (1996). Relations among political attitudes, personality, and psychopathology assessed with new measures of libertarianism and conservatism. Basic and Applied Social Psychology, 18(4), 469-491.

Molero, J. C., \& Pujol, F. (2012). Walking inside the potential tax evader's mind: Tax morale does matter. Journal of Business Ethics, 105(2), 151-162. 
Oppenheimer, D. M., Meyvis, T., \& Davidenko, N. (2009). Instructional manipulation checks: Detecting satisficing to increase statistical power. Journal of Experimental Social Psychology, 45(4), 867-872.

Paolacci, G., \& Chandler, J. (2014). Inside the Turk understanding Mechanical Turk as a participant pool. Current Directions in Psychological Science, 23(3), 184-188.

PricewaterhouseCoopers (PwC) (2013). Tax Strategy and Corporate Reputation: a Tax Issue, a Business Issue. 16th Annual Global CEO Survey: PricewaterhouseCoopers. Available at: $\quad$ https://www.pwc.com/gx/en/tax/publications/assets/pwc-tax-strategy-and-corporatereputation.pdf

Scheffer, D. (2013). The ethical imperative of curbing corporate tax avoidance. Ethics \& International Affairs, 27(4), 361-369.

Scheiber, N. \& Cohen, P. (2015). For the wealthiest, a private tax system that saves them billions. The New Times. Available at: http://www.nytimes.com/2015/12/30/business/economy/for-the-wealthiest-private-taxsystem-saves-them-billions.html? $\mathrm{r}=0$

Sen, S., Bhattacharya, C. B., \& Korschun, D. (2006). The role of corporate social responsibility in strengthening multiple stakeholder relationships: A field experiment. Journal of the Academy of Marketing Science, 34(2), 158-166.

Sikka, P. (2010). Smoke and mirrors: Corporate social responsibility and tax avoidance. Accounting Forum, 34(3), 153-168.

Sikka, P., \& Willmott, H. (2013). The tax avoidance industry: Accountancy firms on the make. Critical Perspectives on International Business, 9(4), 415-443. 
Skarmeas, D., \& Leonidou, C. N. (2013). When consumers doubt, watch out! The role of CSR skepticism. Journal of Business Research, 66(10), 1831-1838.

Skowronski, J. J., \& Carlston, D. E. (1992). Caught in the act: When impressions based on highly diagnostic behaviours are resistant to contradiction. European Journal of Social Psychology, 22, 435-452.

Smith, C. (2003). Moral, believing animals: Human personhood and culture. Oxford, UK: Oxford.

Sweetin, V. H., Knowles, L. L., Summey, J. H., \& McQueen, K. S. (2013). Willingness-topunish the corporate brand for corporate social irresponsibility. Journal of Business Research, 66(10), 1822-1830.

Tax Justice Network Australia. (2014). Who pays for our Common Wealth? - Tax Practices of the ASX 200. Available at: http://www.unitedvoice.org.au/news/who-pays-ourcommon-wealth

Torgler, B., \& Schneider, F. (2007). What shapes attitudes toward paying taxes? Evidence from multicultural European countries. Social Science Quarterly, 88(2), 443-470.

Trudel, R., \& Cotte, J. (2009). Does it pay to be good? MIT Sloan Management Review, $50(2), 61-68$.

Trump, R. K. (2014). Connected consumers' responses to negative brand actions: The roles of transgression self-relevance and domain. Journal of Business Research, 67(9), 1824 1830. 
Vonk, R. (1999). Differential evaluations of likeable and dislikeable behaviours enacted towards superiors and subordinates. European Journal of Social Psychology, 29(23), 139146.

Ybarra, O. (2002). Naive causal understanding of valenced behaviors and its implications for social information processing. Psychological Bulletin, 128(3), 421-441.

Zhao, X., Lynch, J. G., \& Chen, Q. (2010). Reconsidering Baron and Kenny: Myths and truths about mediation analysis. Journal of Consumer Research, 37(2), 197-206. 


\section{Conceptual model for Aggressive CTSs}

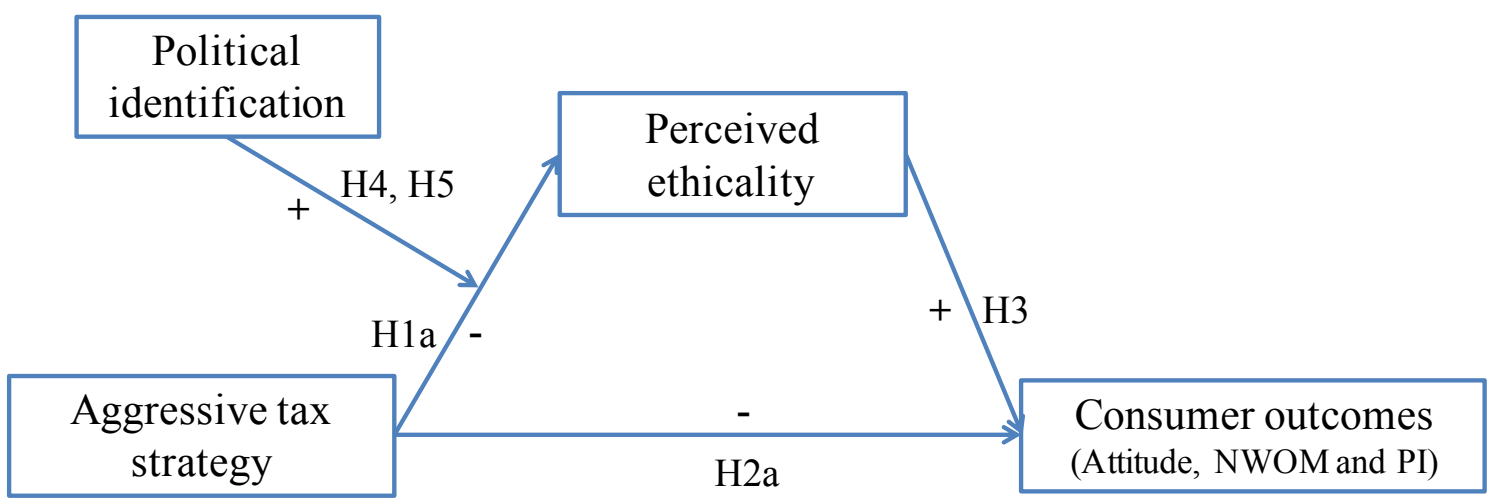

\section{Conceptual model for Conservative CTSs}

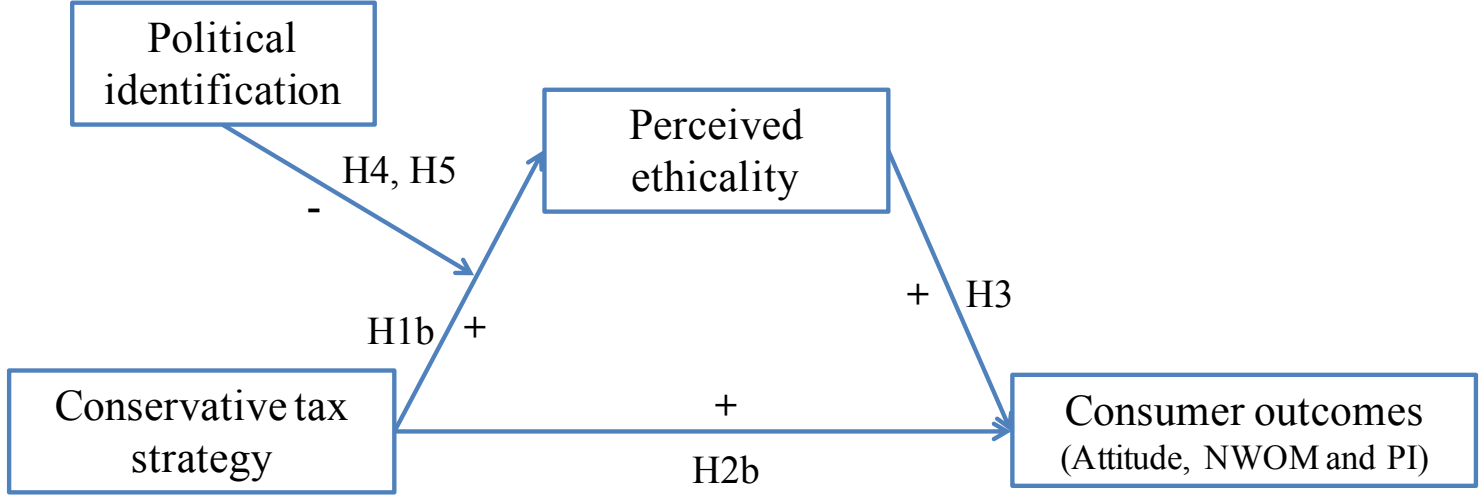

Figure 1: Conceptual models 


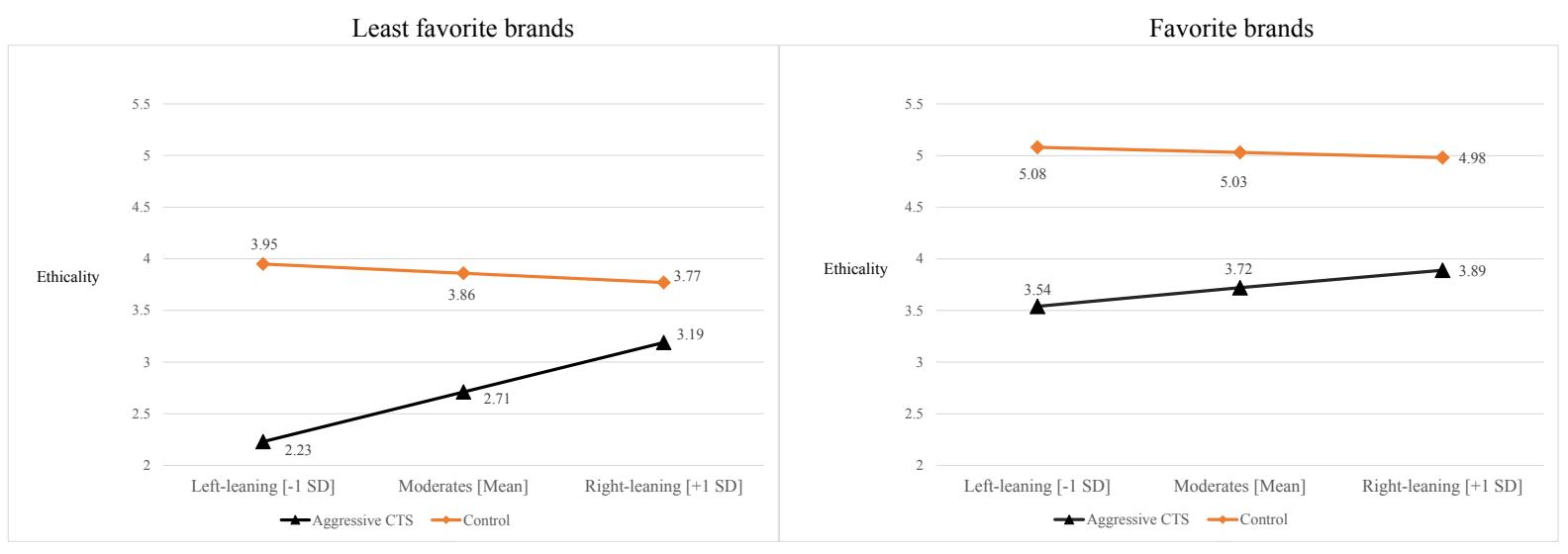

Figure 2: Interaction of Aggressive CTS and political identification for favorite and least favorite brands 


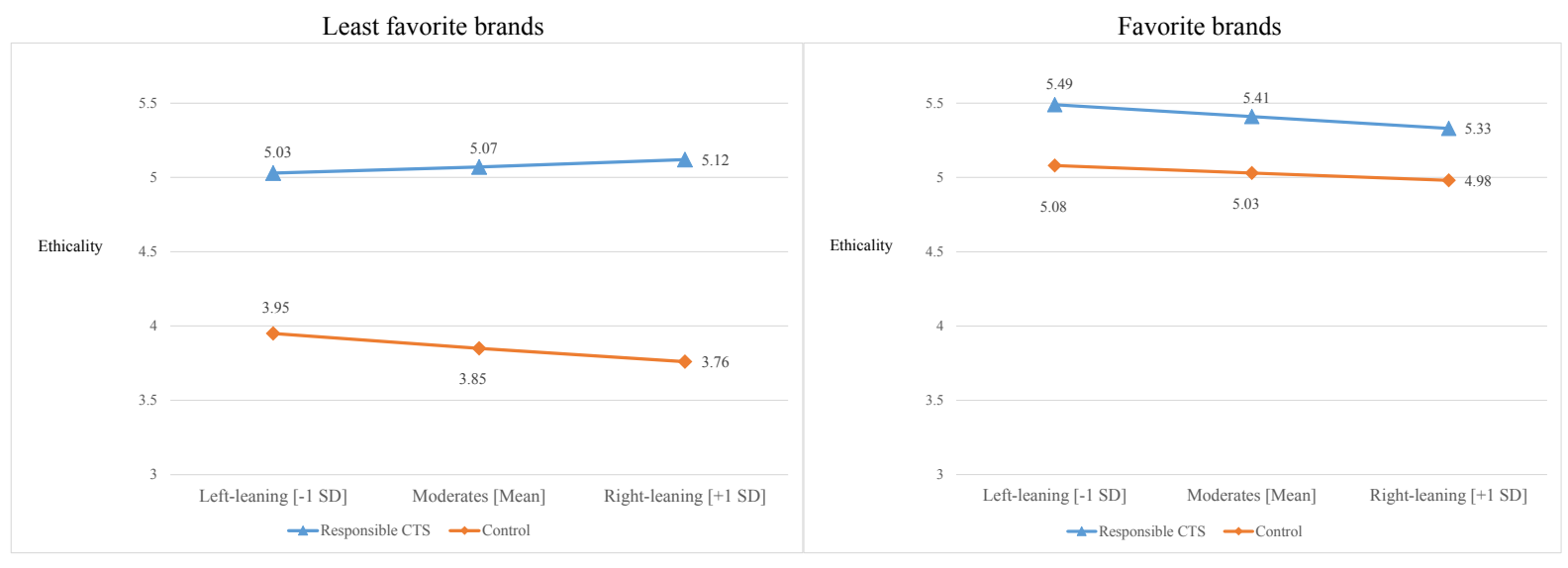

Figure 3: Interaction of Conservative CTS and political identification for favorite and least favorite brands 
Table 1: Means across conditions (Study 1)

\begin{tabular}{|l|c|c|c|c|c|c|}
\hline & \multicolumn{2}{|c|}{$\begin{array}{c}\text { Aggressive } \\
\text { CTSs condition } \\
(\mathrm{N}=137)\end{array}$} & \multicolumn{2}{c|}{$\begin{array}{c}\text { Conservative } \\
\text { CTSs condition } \\
(\mathrm{N}=130)\end{array}$} & \multicolumn{2}{c|}{$\begin{array}{c}\text { Control CTSs } \\
\text { condition } \\
(\mathrm{N}=135)\end{array}$} \\
\hline & Mean & SD & Mean & SD & Mean & SD \\
\hline $\begin{array}{l}\text { Perceived } \\
\text { ethicality }\end{array}$ & $3.10^{* *}$ & 1.39 & $5.30^{* *}$ & 1.06 & 4.46 & 1.00 \\
\hline Attitudes & $3.34^{* *}$ & 1.68 & $5.36^{* *}$ & 1.23 & 5.00 & 1.28 \\
\hline NWOM & $3.82^{* *}$ & 1.77 & 2.12 & 1.15 & 2.28 & 1.25 \\
\hline $\begin{array}{l}\text { Purchase } \\
\text { intentions }\end{array}$ & $3.30^{* *}$ & 1.62 & 4.81 & 1.23 & 4.63 & 1.20 \\
\hline
\end{tabular}

** indicate that the values are significantly different from the control at the $p<.01$ significance level. Pairwise comparisons calculated using planned contrasts. 
Table 2: Moderated-mediation model (Study 1)

\begin{tabular}{|c|c|c|}
\hline CTS & Path & Estimate \\
\hline \multirow{8}{*}{ Aggressive CTS } & Aggressive CTS vs Control $\rightarrow$ Perceived ethicality & $-1.03^{* *}$ \\
\hline & Aggressive CTS vs Control $\rightarrow$ Attitudes & $-.20^{* *}$ \\
\hline & Aggressive CTS vs Control $\rightarrow$ PI & $-.04^{\mathrm{NS}}$ \\
\hline & Aggressive CTS vs Control $\rightarrow$ NWOM & $.26^{* *}$ \\
\hline & Perceived ethicality $\rightarrow$ Attitudes & $.93^{* *}$ \\
\hline & Perceived ethicality $\rightarrow$ PI & $.91^{* *}$ \\
\hline & Perceived ethicality $\rightarrow$ NWOM & $-.74^{* *}$ \\
\hline & $\begin{array}{l}\text { Aggressive CTS vs Control * Political identification } \rightarrow \\
\text { Perceived ethicality }\end{array}$ & $.08^{*}$ \\
\hline \multirow{8}{*}{ Conservative CTS } & Conservative CTS vs Control $\rightarrow$ Perceived ethicality & $.71^{* *}$ \\
\hline & Conservative CTS vs Control $\rightarrow$ Attitudes & $-.18^{* *}$ \\
\hline & Conservative CTS vs Control $\rightarrow$ PI & $.19^{* *}$ \\
\hline & Conservative CTS vs Control $\rightarrow$ NWOM & $-.24^{* *}$ \\
\hline & Perceived ethicality $\rightarrow$ Attitudes & $.85^{* *}$ \\
\hline & Perceived ethicality $\rightarrow$ PI & $.79^{* *}$ \\
\hline & Perceived ethicality $\rightarrow$ NWOM & $-.65^{* *}$ \\
\hline & $\begin{array}{l}\text { Aggressive CTS vs Control * Political identification } \rightarrow \\
\text { Perceived ethicality }\end{array}$ & $-.06^{*}$ \\
\hline
\end{tabular}

indicates that the value is significant at $p<.05$ significance level. ${ }^{* *}$ indicates that the value is significant at $p$ $<.01$ significance level, ${ }^{\mathrm{NS}}$ indicates that $p>.05$. Unstandardized beta values reported. Model estimated using PROCESS, Model 7 (Hayes, 2013). 
Table 3: Conditional indirect effects (Study 1)

\begin{tabular}{|c|c|c|c|c|}
\hline & & $\begin{array}{c}\text { Left-leaning } \\
(-1 \mathrm{SD})\end{array}$ & $\begin{array}{c}\text { Moderates } \\
\text { Mean } \\
\end{array}$ & $\begin{array}{c}\text { Right-leaning } \\
(+1 \mathrm{SD})\end{array}$ \\
\hline \multirow{3}{*}{$\begin{array}{l}\text { Aggressive } \\
\text { tax strategy }\end{array}$} & $\begin{array}{l}\text { Aggressive tax strategy } \rightarrow \\
\text { Perceived Ethicality } \rightarrow \text { Attitudes }\end{array}$ & $\begin{array}{c}-.80 \\
\text { (CI from }-.98 \\
\text { to }-.62)\end{array}$ & $\begin{array}{c}-.65 \\
(\mathrm{CI} \text { from }-.78 \\
\text { to }-.52)\end{array}$ & $\begin{array}{c}-.49 \\
(\mathrm{CI} \text { from }-.68 \\
\text { to }-.29)\end{array}$ \\
\hline & $\begin{array}{l}\text { Aggressive tax strategy } \rightarrow \\
\text { Perceived Ethicality } \rightarrow \text { NWOM }\end{array}$ & $\begin{array}{c}.64 \\
\text { (CI from .48 } \\
\text { to } .83) \\
\end{array}$ & $\begin{array}{c}.52 \\
\text { (CI from } .39 \\
\text { to } .67) \\
\end{array}$ & $\begin{array}{c}.39 \\
\text { (CI from } .23 \\
\text { to } .58) \\
\end{array}$ \\
\hline & $\begin{array}{l}\text { Aggressive tax strategy } \rightarrow \\
\text { Perceived Ethicality } \rightarrow \text { PI }\end{array}$ & $\begin{array}{c}-.78 \\
(\mathrm{CI} \text { from }-.97 \\
\text { to }-.60)\end{array}$ & $\begin{array}{c}-.63 \\
(\mathrm{CI} \text { from }-.76 \\
\text { to }-.51)\end{array}$ & $\begin{array}{c}-.48 \\
(\mathrm{CI} \text { from }-.66 \\
\text { to }-.29)\end{array}$ \\
\hline \multirow{3}{*}{$\begin{array}{l}\text { Conservative } \\
\text { tax strategy }\end{array}$} & $\begin{array}{l}\text { Conservative tax strategy } \rightarrow \\
\text { Perceived Ethicality } \rightarrow \text { Attitudes }\end{array}$ & $\begin{array}{c}.48 \\
\text { (CI from } .31 \\
\text { to } .69)\end{array}$ & $\begin{array}{c}.36 \\
\text { (CI from } .24 \\
\text { to } .49)\end{array}$ & $\begin{array}{c}.23 \\
\text { (CI from } .09 \\
\text { to } .38)\end{array}$ \\
\hline & $\begin{array}{l}\text { Conservative tax strategy } \rightarrow \\
\text { Perceived Ethicality } \rightarrow \text { NWOM }\end{array}$ & $\begin{array}{c}-.37 \\
\text { (CI from }-.56 \\
\text { to }-.22)\end{array}$ & $\begin{array}{c}-.27 \\
\text { (CI from }-.41 \\
\text { to }-.17)\end{array}$ & $\begin{array}{c}-.17 \\
(\mathrm{CI} \text { from }-.30 \\
\text { to }-.07)\end{array}$ \\
\hline & $\begin{array}{l}\text { Conservative tax strategy } \rightarrow \\
\text { Perceived Ethicality } \rightarrow \text { PI }\end{array}$ & $\begin{array}{c}.45 \\
\text { (CI from } .29 \\
\text { to } .63) \\
\end{array}$ & $\begin{array}{c}.33 \\
(\mathrm{CI} \text { from } .23 \\
\text { to } .45)\end{array}$ & $\begin{array}{c}.21 \\
(\mathrm{CI} \text { from } .08 \\
\text { to } .35)\end{array}$ \\
\hline
\end{tabular}


Table 4: Means across conditions (Study 2)

\begin{tabular}{|c|c|c|c|c|c|c|c|c|c|c|}
\hline & \multicolumn{2}{|c|}{$\begin{array}{c}\text { Aggressive } \\
\text { CTSs } \\
\text { condition } \\
\end{array}$} & \multicolumn{2}{|c|}{$\begin{array}{c}\text { Conservative } \\
\text { CTSs } \\
\text { condition } \\
\end{array}$} & \multicolumn{2}{|c|}{$\begin{array}{c}\text { Control } \\
\text { condition }\end{array}$} & \multicolumn{2}{|c|}{ Favorite brands } & \multicolumn{2}{|c|}{$\begin{array}{l}\text { Least favorite } \\
\text { brands }\end{array}$} \\
\hline & \multicolumn{2}{|c|}{$\mathrm{N}=102$} & \multicolumn{2}{|c|}{$\mathrm{N}=102$} & \multicolumn{2}{|c|}{$\mathrm{N}=102$} & \multicolumn{2}{|c|}{$\mathrm{N}=153$} & \multicolumn{2}{|c|}{$\mathrm{N}=153$} \\
\hline & Mean & $S D$ & Mean & $S D$ & Mean & $S D$ & Mean & $S D$ & Mean & $S D$ \\
\hline $\begin{array}{l}\text { Perceived } \\
\text { ethicality }\end{array}$ & $3.19^{* *}$ & 1.44 & $5.25^{* *}$ & 0.99 & 4.44 & 0.99 & $4.71^{* *}$ & 1.36 & 3.88 & 1.39 \\
\hline Attitudes & $3.56^{* *}$ & 1.82 & $4.85^{*}$ & 1.60 & 4.48 & 1.83 & $5.45^{* *}$ & 1.45 & 3.15 & 1.39 \\
\hline NWOM & $3.54^{* *}$ & 1.69 & 2.19 & 1.25 & 2.49 & 1.37 & 2.39 & 1.42 & $3.09^{* *}$ & 1.61 \\
\hline PI & $3.63^{* *}$ & 2.01 & 4.18 & 1.86 & 4.11 & 2.09 & $5.55^{* *}$ & 1.23 & 2.39 & 1.22 \\
\hline $\begin{array}{l}\text { indicates } \\
\text { control at } \\
\text { different } \mathrm{fl}\end{array}$ & $\begin{array}{l}\text { that th } \\
<.05 \\
m \text { the } c\end{array}$ & $\begin{array}{l}\text { value } \\
\text { indic } \\
\text { trol at }\end{array}$ & $\begin{array}{l}\text { statisti } \\
\text { es that } \\
<.01\end{array}$ & $\begin{array}{l}\text { lly } \mathrm{d} \\
\text { he val }\end{array}$ & $\begin{array}{l}\text { rent } f \\
\text { is sta }\end{array}$ & $\begin{array}{l}\mathrm{n} \text { the } \\
\text { ically }\end{array}$ & $\begin{array}{l}{ }^{* *} \text { indicat } \\
\text { different }\end{array}$ & $\begin{array}{l}t \text { the } v \\
.01\end{array}$ & is stat & \\
\hline
\end{tabular}


Table 5: Moderated-mediation model (Study 2)

\begin{tabular}{|c|c|c|}
\hline CTS & Path & Estimate \\
\hline \multirow{8}{*}{ Aggressive CTS } & Aggressive CTS vs Control $\rightarrow$ Perceived ethicality & $-1.02^{* *}$ \\
\hline & Aggressive CTS vs Control $\rightarrow$ Attitudes & $.17^{\mathrm{NS}}$ \\
\hline & Aggressive CTS vs Control $\rightarrow$ PI & $.47^{* *}$ \\
\hline & Aggressive CTS vs Control $\rightarrow$ NWOM & $.16^{\mathrm{NS}}$ \\
\hline & Perceived ethicality $\rightarrow$ Attitudes & $1.01^{* *}$ \\
\hline & Perceived ethicality $\rightarrow$ PI & $1.14^{* *}$ \\
\hline & Perceived ethicality $\rightarrow$ NWOM & $-.59^{* *}$ \\
\hline & $\begin{array}{l}\text { Aggressive CTS vs Control * Political identification } \rightarrow \\
\text { Perceived ethicality }\end{array}$ & $.09^{*}$ \\
\hline \multirow{8}{*}{ Conservative CTS } & Conservative CTS vs Control $\rightarrow$ Perceived ethicality & $.37^{* *}$ \\
\hline & Conservative CTS vs Control $\rightarrow$ Attitudes & $-.23^{* *}$ \\
\hline & Conservative CTS vs Control $\rightarrow$ PI & $-.39^{* *}$ \\
\hline & Conservative CTS vs Control $\rightarrow$ NWOM & $.06^{\mathrm{NS}}$ \\
\hline & Perceived ethicality $\rightarrow$ Attitudes & $1.05^{* *}$ \\
\hline & Perceived ethicality $\rightarrow$ PI & $1.06^{* *}$ \\
\hline & Perceived ethicality $\rightarrow$ NWOM & $-.53^{* *}$ \\
\hline & $\begin{array}{l}\text { Aggressive CTS vs Control * Political identification } \rightarrow \\
\text { Perceived ethicality }\end{array}$ & $-.01^{\mathrm{NS}}$ \\
\hline
\end{tabular}

indicates that the value is significant at $p<.05$ significance level. ${ }^{* *}$ indicates that the value is significant at $p$ $<.01$ significance level, ${ }^{\mathrm{NS}}$ indicates that $p>.05$. Unstandardized beta values reported. Model estimated using PROCESS, Model 7 (Hayes, 2013). 
Table 6: Conditional indirect effects for the entire sample (Study 2)

\begin{tabular}{|c|c|c|c|c|}
\hline & & $\begin{array}{c}\text { Left-leaning } \\
(-1 \mathrm{SD})\end{array}$ & $\begin{array}{c}\text { Moderates } \\
\text { Mean }\end{array}$ & $\begin{array}{c}\text { Right-leaning } \\
(+1 \mathrm{SD})\end{array}$ \\
\hline \multirow{3}{*}{$\begin{array}{l}\text { Aggressive } \\
\text { tax strategy }\end{array}$} & $\begin{array}{l}\text { Aggressive tax strategy } \rightarrow \\
\text { Perceived Ethicality } \rightarrow \text { Attitudes }\end{array}$ & $\begin{array}{c}-.93 \\
\text { (CI from }-1.21 \\
\text { to }-.65)\end{array}$ & $\begin{array}{c}-.69 \\
(\mathrm{CI} \text { from }-.91 \\
\text { to }-.49)\end{array}$ & $\begin{array}{c}-.46 \\
\text { (CI from }-.77 \\
\text { to }-.17)\end{array}$ \\
\hline & $\begin{array}{l}\text { Aggressive tax strategy } \rightarrow \\
\text { Perceived Ethicality } \rightarrow \text { NWOM }\end{array}$ & $\begin{array}{c}.48 \\
\text { (CI from } .29 \\
\text { to } .70)\end{array}$ & $\begin{array}{c}.35 \\
(\mathrm{CI} \text { from } .22 \\
\text { to } .52)\end{array}$ & $\begin{array}{c}.24 \\
\text { (CI from } .09 \\
\text { to } .43)\end{array}$ \\
\hline & $\begin{array}{l}\text { Aggressive tax strategy } \rightarrow \\
\text { Perceived Ethicality } \rightarrow \text { PI }\end{array}$ & $\begin{array}{c}-.93 \\
(\mathrm{CI} \text { from }-1.22 \\
\text { to }-.65)\end{array}$ & $\begin{array}{c}-.69 \\
(\mathrm{CI} \text { from }-.91 \\
\text { to }-.50)\end{array}$ & $\begin{array}{c}-.46 \\
\text { (CI from }-.78 \\
\text { to }-.17)\end{array}$ \\
\hline
\end{tabular}


Table 7: Conditional indirect effects for least favorite brands (Study 2)

\begin{tabular}{|l|l|c|c|c|}
\hline & & $\begin{array}{c}\text { Left-leaning } \\
(-1 \mathrm{SD})\end{array}$ & $\begin{array}{c}\text { Moderates } \\
\text { Mean }\end{array}$ & $\begin{array}{c}\text { Right-leaning } \\
\text { (+1 } \mathrm{SD})\end{array}$ \\
\hline \multirow{4}{*}{$\begin{array}{l}\text { Aggressive } \\
\text { tax strategy }\end{array}$} & $\begin{array}{l}\text { Aggressive tax strategy } \rightarrow \\
\text { Perceived Ethicality } \rightarrow \text { Attitudes }\end{array}$ & $\begin{array}{c}-.66 \\
\text { (CI from }-.84 \\
\text { to }-.49)\end{array}$ & $\begin{array}{c}-.44 \\
\text { (CI from }-.61 \\
\text { to }-.29)\end{array}$ & $\begin{array}{c}-.22 \\
\text { (CI from }-.47 \\
\text { to }-.009)\end{array}$ \\
\cline { 2 - 6 } & $\begin{array}{l}\text { Aggressive tax strategy } \rightarrow \\
\text { Perceived Ethicality } \rightarrow \text { NWOM }\end{array}$ & $\begin{array}{c}.48 \\
\text { (CI from } .29 \\
\text { to } .70)\end{array}$ & $\begin{array}{c}.35 \\
\text { (CI from } .22 \\
\text { to } .52)\end{array}$ & $\begin{array}{c}.24 \\
\text { (CI from } .09 \\
\text { to } .43)\end{array}$ \\
\cline { 2 - 6 } & $\begin{array}{l}\text { Aggressive tax strategy } \rightarrow \\
\text { Perceived Ethicality } \rightarrow \text { PI }\end{array}$ & $\begin{array}{c}-.62 \\
\text { (CI from }-.83 \\
\text { to }-.44)\end{array}$ & $\begin{array}{c}-.42 \\
\text { (CI from }-.59 \\
\text { to }-.28)\end{array}$ & $\begin{array}{c}-.21 \\
\text { (CI from }-.46 \\
\text { to }-.009)\end{array}$ \\
\hline
\end{tabular}

